\title{
Evolution Logic and Comparative Advantage of China's Power System Reform - A Comparative Study on Transmission Management Between China and the United States
}

\author{
Wei-ping Wu ${ }^{1,2}$, Wei-kang Zeng ${ }^{1}, \mathrm{Li}_{\text {-fan }} \mathrm{Lu}^{1 *}$ and Zi-gui Chen ${ }^{1,3 *}$ \\ ${ }^{1}$ Key Laboratory of Digital Economy and High Quality Development, Hunan University of Technology and Business, \\ Changsha, China, ${ }^{2}$ School of Economy \& Trade, Hunan University, Changsha, China, ${ }^{3}$ Design and Art Institute, Hunan \\ University of Technology and Business, Changsha, China
}

OPEN ACCESS

Edited by:

Chan Wang,

Guangdong University of Finance and Economics, China

Reviewed by:

Vincent Chen,

The University of Sheffield,

United Kingdom

Ze-zhou Wen,

Huazhong University of Science and Technology, China

${ }^{*}$ Correspondence:

Li-fan Lu

Iulifan0107@163.com

Zi-gui Chen

chenzigui0213@163.com

Specialty section: This article was submitted to Sustainable Energy Systems and Policies,

a section of the journal Frontiers in Energy Research

Received: 25 March 2021 Accepted: 06 April 2021 Published: 30 April 2021

Citation:

Wu W-p, Zeng W-k, Lu L-f and Chen Z-g (2021) Evolution Logic and Comparative Advantage of China's Power System Reform - A Comparative Study on Transmission Management Between China and the United States.

Front. Energy Res. 9:685735. doi: 10.3389/fenrg.2021.685735
This paper examines the differences of power systems between China and the United States from the perspective of transmission management, and finally summarizes the institutional advantages of China's power system reform. The research shows that there are significant operation and supervision differences between China and the United States in transmission management. China has always maintained a unified management in transmission management, while the United States has adopted a decentralized management model in transmission. The implementation of centralized unified management in transmission links cannot only ensure the timely and effective allocation of national power energy, but also be helpful to concentrate all kinds of resources to develop large-scale power projects.

Keywords: power systems reform, transmission management, institutional advantages, China, the United States

\section{INTRODUCTION}

Every leap of productivity in human society is accompanied by the improvement and replacement of energy. "Electric power revolution" has greatly improved the efficiency of social operation, and also tends to industrialization with the rising social demand (Rothe, 2019). Power industry has natural monopoly, and monopoly always leads to low efficiency. In the 1990s, the United States, Japan and some European developed countries have carried out the market-oriented reform of power system, trying to break the low efficiency of monopoly through the reform of system and mechanism, and further optimize the allocation of power resources, so that the power system can better serve the social and economic development (Michaels, 2006). But things were ordered otherwise. The power outage in Texas in 2021 reflects the significant security risks brought by the segmented grid management to the stable operation system under the market-oriented reform.

In the early days of the founding of new China, the Chinese central government found that there were various drawbacks in the decentralized management of power grid, which seriously affected the stability and development of the power industry. Thus, the long-term centralized management of China's power system has become a feature of the economic planning. With the advancement of China's socialist market economic system reform, the problems of unclear management responsibility and inefficient operation of enterprises caused by the "integration of government and enterprise" in the power system are gradually exposed, so the central government has issued a series of policy documents 
aimed at giving full play to the power's role in ensuring social and economic development. In 2002, the State Council issued the Power System Reform Plan, marking the formal opening of the power system reform of "separation of power plant and power grid," in order to introduce competition in the generation side to improve the efficiency of the power system. In 2015, the State Council issued Several Opinions on Further Deepening the Reform of Power System, focusing on solving five major problems, such as the lag of legislative amendment law, the lack of trading mechanism, the perfection of coordination mechanism, incomplete pricing mechanism and imperfect development mechanism. Both the vertical historical experience and the horizontal comparison between countries have proved that China's power system has its unique advantages in transmission management.

This paper analyzes the differences of power transmission management between China and the United States from the perspective of historical evolution (Figure 1), and finally summarizes the institutional advantages and optimization measures of China's power system reform.

\section{THE EVOLUTION OF POWER SYSTEM REFORM IN CHINA AND THE UNITED STATES}

In the 1980s-1990s, with the development of market economy, the incompatibility of power system policies originated from the planned period has become increasingly prominent in the market economy. Under the planned economy, the "un-separation of government and enterprise" cannot guarantee the effective management of the power system by government departments, and it is difficult to improve the market efficiency of the power industry, which hinders the further development of the power industry. Moreover, the experience from other countries shows that the power industry does not need the integration of generation, transmission, distribution and sales (Chawla and Pollitt, 2013). Based on the consideration of enhancing the effective management of power system and improving the market efficiency of power industry, China's power system reform is imminent (Bai, 2019).

In January 1997, the State Council decided to establish the state power company, which marked the transition of China's power management system from planned economy to socialist market economy, and laid the foundation for the reform of China's power system. In February 2002, the Power System Reform Plan was issued by the State Council, marking the official opening of China's power system reform. In March 2003, the State Electricity Regulatory Commission (SERC) was established, whose responsibility is to supervise and manage the operation order of the power market. In March 2013, the State Council decided to integrate the responsibilities of the National Energy Administration (NEA) and SERC to further improve the energy management system. In April 2015, the State Council issued Several Opinions on Further Deepening the Power System Reform, which started a new round of China's power system reform, focusing on solving such important problems as the lack of power system market trading mechanism, imperfect power system planning coordination mechanism, and difficulties in the development and utilization of emerging energy. In November 2017, the National Development and Reform Commission (NDRC) and NEA issued the notice on Accelerating the Pilot Reform of Incremental Distribution Business, and clearly defined the goal of deepening the reform focusing on the marketization of incremental distribution and direct transactions between power plants and power users. In a word, the reform of China's electric power system not only strengthens the management of the state in the transmission link, but also improves the market allocation efficiency of power generation and sales, and realizes the unity of power system stability and efficiency to a certain extent (Table 1).

The development of the United States power industry is relatively mature, and its power system has undergone many rounds of reform. Its power reform mainly revolves around breaking the integration, liberalizing the control of power generation and distribution terminal, realizing free competition, and maintaining the monopoly of transmission terminal at the same time. The reform of the United States power system began with the Energy Policy Act of October 1992, which establishes the separation of power generation, transmission and distribution, to eliminate the monopoly of power industry and promote market competition and technological progress. In 1996, the Federal Energy Regulatory Commission (FERC) issued orders 888 and 889 , requiring power companies with transmission facilities to open up the transmission network. In response to the FERC act, some power companies in the United States spontaneously joined forces and formed an Independent System Operation Company (ISO). In December 1999, FERC issued another order 2000, facilitating the establishment of Regional Transmission Organizations (RTO), and requiring all public utility companies with transmission networks to join RTO. Actually, the function of RTO is similar to ISO, but it adds the function of trans-regional transmission network planning and reliability maintenance on the basis of ISO. In 2003, ISO and RTO jointly established a power industry cooperation organization in most parts of the United States, called the ISO/RTO Committee (IRC).

In August 2005, the Energy Policy Act 2005 of the United States was promulgated, which aimed to optimize the energy use structure of the United States and promote competition in the wholesale electricity market. Since then, FERC issued a series of decrees from 2006 to 2015, trying to further improve the level of power system marketization from the aspects of pricing, trading and management. However, due to the implementation of private ownership in the transmission sector in the United States, and the overlapping regulatory functions among different organizations, the unified centralized management of transmission has not yet been realized.

\section{DIFFERENCES OF TRANSMISSION MANAGEMENT SYSTEM BETWEEN CHINA AND THE UNITED STATES}

On the whole, the goal of power system reform in China and the United States is to establish a competitive power market, but the 


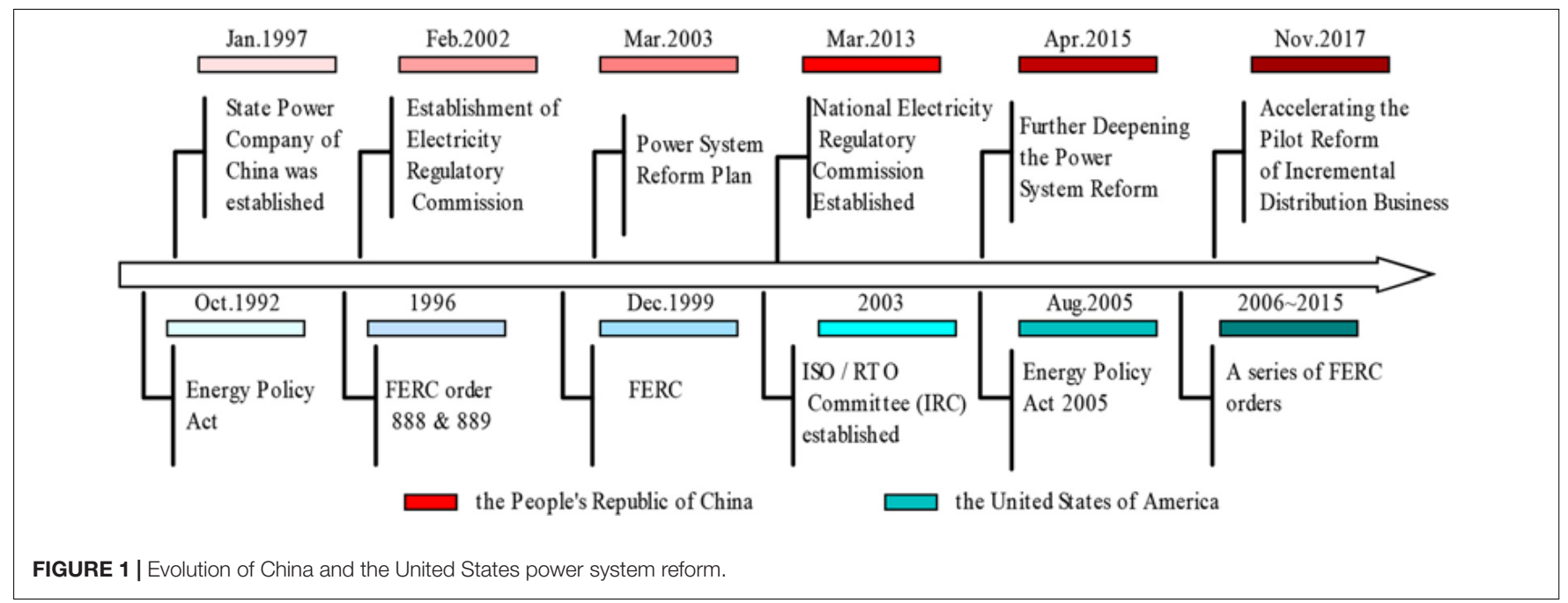

TABLE 1 | Policies and contents of power system reform in China and the United States.

\begin{tabular}{|c|c|c|c|}
\hline \multicolumn{2}{|r|}{ China } & \multicolumn{2}{|r|}{ The United States } \\
\hline Policies & Content & Policies & Content \\
\hline $\begin{array}{l}\text { Establishment of the state } \\
\text { power company of China }\end{array}$ & $\begin{array}{l}\text { - Company system reform of Ministry of electric } \\
\text { power industry } \\
\text { - set up a state-owned power company }\end{array}$ & Energy Policy Act & $\begin{array}{l}\text { - Non-public companies are allowed to enter the } \\
\text { wholesale electricity market } \\
\text { - Transmission companies provide transmission } \\
\text { services at reasonable prices }\end{array}$ \\
\hline $\begin{array}{l}\text { The power system reform } \\
\text { plan }\end{array}$ & $\begin{array}{l}\text { - The assets of the State Power Company were } \\
\text { reorganized into } 5 \text { power generation companies } \\
\text { and } 2 \text { transmission and distribution companies } \\
\text { - Establishment of a power dispatching and } \\
\text { trading center implementation of electricity } \\
\text { bidding online } \\
\text { - Electricity price is divided into feed-in price, } \\
\text { transmission price, distribution price and } \\
\text { terminal selling price }\end{array}$ & $\begin{array}{l}\text { Federal Energy } \\
\text { Commission Decrees } \\
\text { No.888 and No. } 889\end{array}$ & $\begin{array}{l}\text { Open and fair access for all utility companies through } \\
\text { open grid } \\
\text { - Promoting the competition in the wholesale electricity } \\
\text { market. }\end{array}$ \\
\hline SERC established & $\begin{array}{l}\text { - Power market regulation and operation } \\
\text { supervision } \\
\text { - Put forward price adjustment suggestions to } \\
\text { government price department }\end{array}$ & $\begin{array}{l}\text { Federal Energy } \\
\text { Commission Decrees } \\
\text { No. } 2000\end{array}$ & $\begin{array}{l}\text { - All utility companies with transmission network join } \\
\text { regional transmission organization (RTO) }\end{array}$ \\
\hline SERC merged with NEA & $\begin{array}{l}\text { - Realizing the integration of power regulatory } \\
\text { responsibilities } \\
\text { - Improve the energy management system }\end{array}$ & IRC established & $\begin{array}{l}\text { - Coordinate and manage power systems in different } \\
\text { regions }\end{array}$ \\
\hline $\begin{array}{l}\text { Further deepening the } \\
\text { power system reform }\end{array}$ & $\begin{array}{l}\text { - Orderly deregulation of electricity price in } \\
\text { competitive links other than transmission and } \\
\text { distribution } \\
\text { - Promote the independent and standardized } \\
\text { operation of trading institutions } \\
\text { - The profit model of electric power company is } \\
\text { changed into the model combining cost and } \\
\text { profit }\end{array}$ & Energy Policy Act 2005 & $\begin{array}{l}\text { Promoting competition in wholesale electricity market } \\
\text { - Improve the competition level of power market }\end{array}$ \\
\hline $\begin{array}{l}\text { Accelerating the pilot } \\
\text { reform of incremental } \\
\text { distribution business }\end{array}$ & $\begin{array}{l}\text { - Increase the pilot scope of incremental } \\
\text { distribution business reform } \\
\text { - Further deregulation of power distribution }\end{array}$ & $\begin{array}{l}\text { Federal Energy } \\
\text { Commission Decrees } \\
\text { No.681, 719, 768, 816, } \\
890,1000\end{array}$ & $\begin{array}{l}\text { - Establish guidelines and operational rules for } \\
\text { independent transmission organizations } \\
\text { - Improve the operation ability and market competition } \\
\text { of wholesale electricity market } \\
\text { - Refine market pricing policies and procedures } \\
\text { - Optimization of transmission network open access } \\
\text { control framework } \\
\text { - Improve transmission cost and cost allocation } \\
\text { mechanism of power grid access }\end{array}$ \\
\hline
\end{tabular}


path choice to achieve the goal is very different, especially in the transmission management.

\section{Operation of Transmission Network}

The distribution of energy resources in China is unbalanced, and there is a large space gap between the power supply center and the power load center in China. This kind of spatial mismatch of power supply and demand objectively requires China to build cross regional UHV power grid. This has created conditions for the construction of the national unified power grid, and gradually formed the power grid pattern of UHV power transmission from west to East and north to south. In natural monopoly industries such as electric power, state-owned capital is dominant. In view of the disadvantages of domestic and foreign power systems in the decentralized management of transmission links, China has not implemented marketization in the transmission link. State Grid and China Southern Power Grid are the two central enterprises to manage and operate the transmission link, and the stateowned capital in the transmission link is centrally managed. Under this kind of management system, the power system puts more emphasis on the overall planning and operation stability. The control of state-owned capital also ensures that largescale construction projects can get sufficient financial support, can realize the efficient allocation of cross regional power, and fully guarantees the integrity and stability of the power system. Under the public ownership, the power industry has made great achievements to meet the continuous and stable growth of power demand (Yu, 2014).

Transmission management in the United States is different from that in China. Its power system has four layers from top to bottom. The first layer is NERC, the second layer is FERC, the third layer is RTO and ISO, and the fourth layer is AEP. The transmission links in the United States are mainly managed by the third and fourth tier power companies. Under the privatization system, the United States has implemented the privatization of the whole process of power generation, transmission, distribution and sales, each power company is a local industry monopolist, and the power enterprises lack the overall dispatching. Due to the decentralization of transmission management functions and the lack of unified power transmission network, one of the hidden dangers is that in case of sudden power crisis, it is impossible to achieve timely and effective cross regional power allocation, which is unfavorable to the overall power stability of the country. In addition, because of the low return rate of power grid investment projects and long construction period, considering the return rate of investment, the private power companies are not willing to make large-scale investment in power grid construction, and even are not willing to upgrade the power grid. So the power supply system is facing a huge challenge of power supply reliability.

\section{Supervision of Transmission Network}

In terms of power regulation, after the first session of the 11th National People's Congress, the National Energy Commission, NEA and the Electricity Regulatory Commission are jointly responsible for Chinass power development planning and market operation regulation. In order to improve the effectiveness of power regulation, in March 2013, the State Council integrated the functions of the former State Power Regulatory Commission into the NEA. Therefore, the national coverage of electric power supervision and unified electric power supervision standards are realized, which effectively avoids the overlapping of electric power supervision functions among different institutions, reduces the time lag of relevant policies in decision-making and implementation, improves the overall efficiency of electric power system.

However, the development process of power system in different regions of the United States is not the same. The power and obligation of power management in different departments are different, and the supervision mode of power wholesale market is also different. There are nine electricity markets in the United States. The management power of power transmission is distributed among RTO, ISO, and AEP, which are at the third and fourth levels of the United States power system. NERC and FERC, which are at a higher level of the power system, are mainly responsible for the work of macro nature, such as the formulation of power industry standards and the management of energy trade. The differentiation of power system regulators and their functions may lead to lack of supervision or overlapping of functions, which will have a negative impact on the efficiency of transmission management, increase the decision-making delay of relevant departments in case of transmission emergency, and may not be able to restore power transmission in time.

\section{INSTITUTIONAL ADVANTAGES OF CHINA'S TRANSMISSION MANAGEMENT}

\section{Timely and Effective National Power Allocation}

China can become one of the few countries in the world without large-scale blackouts for a long time. In 2018, China's average power supply reliability rate is $99.82 \%$, the average outage time of users is $15.75 \mathrm{~h}$ per household, and the average outage frequency of users is 3.28 times per household. In the final analysis, it has a unified power grid management system, which makes the power grid planning, construction, operation, maintenance, dispatching and other links coordinate and operate efficiently, and ensures the long-term safe and stable operation of China's power system. In 2018, China's trans regional power transmission had reached to 136 million KW. Adhering to the integrated management of power grid is conducive to the optimal allocation of new energy in the whole country, the transformation of the energy resource advantages of the western region into economic advantages, and the promotion of the coordinated and balanced development of the national regional economy. Throughout history, in the process of dealing with major natural disasters, it is precisely because of the overall coordination of power grid management and dispatching that accidents can be timely and effectively handled, the losses caused by power accidents can be minimized, and the efficient post disaster reconstruction of power system can be guaranteed (She et al., 2020). 


\section{Concentrating Resources to Develop Large Power Projects}

State Grid and its supporting facilities need to invest a lot of resources. Limited by their own resources, private enterprises are difficult to undertake the nationwide power grid construction. In addition, the profit orientation of private enterprises makes it difficult to maximize social benefits in the construction of power infrastructure. Therefore, in the important infrastructure construction related to the national economy and people's livelihood, the advantages of the Chinese government in concentrating on a large number of systems are fully reflected. Centralized management is conducive to the rational allocation of human, material, financial and intellectual resources, avoiding the negative impact of resource dispersion and excessive capital profit on social development under the privatization system, and improving the construction efficiency and social benefits of largescale power projects to a large extent. In terms of the length of China's power grid lines, in 2018, the length of transmission lines with voltage level of $35 \mathrm{kV}$ and above has reached 1.89 million kilometers, which is equivalent to 47 circles around the earth's equator, 291 times of that in the early days of China. In terms of power technology, the transmission line loss rate of power grid decreased from $23.35 \%$ in 1949 to $6.21 \%$ in 2018 , and the coal consumption of power supply decreased from $1020 \mathrm{kgce} / \mathrm{kwh}$ in 1949 to $308 \mathrm{kgce} / \mathrm{kwh}$ in 2018.

\section{CONCLUSION}

After two effective power system reforms, China has basically achieved the vertical separation of power production, transmission and distribution, breaking the previous monopoly situation of the state power company on all aspects of power production, transmission and distribution, and making the power system more efficient. The centralized and unified management of transmission links and the market-oriented reform of both sides of power generation and distribution effectively realize the balance between power system security and efficiency. However, China still needs to further optimize its power system. Firstly, on the basis of centralized and unified management of transmission links, the competition of

\section{REFERENCES}

Bai, M. (2019). 70 years' development achievements of power industry in New China. Electr. Ind. 229, 18-26.

Chawla, M., and Pollitt, M. G. (2013). Global trends in electricity transmission system operation: where does the future lie? Electr. J. 26, 65-71. doi: 10.1016/j.tej.2013.05.004

Michaels, R. J. (2006). Vertical integration and the restructuring of the U.S. electricity industry. Policy Anal. 572.

Rothe, F. S. (2019). Introduction to Power System Analysis. Hoboken, NJ: John Wiley \& Sons, Ltd.

She, Z. Y., Meng, G., Xie, B. C., and O'Neill, E. (2020). The effectiveness of the unbundling reform in China's power system from a dynamic efficiency perspective. Appl. Energy 264:114717. doi: 10.1016/j.apenergy.2020.114717 different companies in generating and selling electricity is further standardized, so as to ensure the healthy development of power generation enterprises and the power accessibility of the public. Secondly, in terms of improving the functions of the power market, a complete power market integrating spot, long-term and auxiliary services should be established to reduce the impact of emergencies on the power system and improve the quality of power service supply. Thirdly, in terms of energy security, we should further optimize the power generation structure, reduce the dependence of China's power system on thermal power generation, increase the proportion of renewable energy power generation, reduce the potential safety hazard of single power generation mode to power stability, and fulfill China's international commitment of emission reduction and ecological environment protection.

\section{AUTHOR CONTRIBUTIONS}

WW: writing-original draft, methodology, and supervision. WZ: data curation, writing-review, and editing. LL: methodology, writing-review, and editing. ZC: conceptualization and software.

\section{FUNDING}

This research was supported by the National Natural Science Foundation of China (No. 71903056), the National Science Foundation for Post-doctoral Scientists of China (No. 2020M672464), MOE (Ministry of Education in China) Project of Humanities and Social Sciences (No. 19YJC790154), Consulting Project of Chinese Academy of Engineering (Nos. 2020XY-36 and 2019-ZD-38), the Natural Science Foundation of Hunan Province in China (Nos. 2020JJ5104, 2020JJ4259, and 2020JJ5111), Philosophy and Social Science Foundation of Hunan Province in China (No. 18YBQ075), Project of Hunan Social Science Achievement Appraisal Committee (Nos. XSP20YBZ081 and XSP21YBZ094), Scientific Research Project of Hunan Education Department in China (No. 19C1038), and Research and Innovation Project for Graduate Students in Hunan Province (Nos. CX20201083 and CX20201084).

Yu, H. (2014). The ascendency of state-owned enterprises in china: development, controversy and problems. J. Contemp. China 23, 161-182. doi: 10.1080/ 10670564.2013 .809990

Conflict of Interest: The authors declare that the research was conducted in the absence of any commercial or financial relationships that could be construed as a potential conflict of interest.

Copyright (c) $2021 \mathrm{Wu}$, Zeng, Lu and Chen. This is an open-access article distributed under the terms of the Creative Commons Attribution License (CC BY). The use, distribution or reproduction in other forums is permitted, provided the original author(s) and the copyright owner(s) are credited and that the original publication in this journal is cited, in accordance with accepted academic practice. No use, distribution or reproduction is permitted which does not comply with these terms. 